\title{
INVESTIGASI SEGMENTASI BARIS UNTUK CITRA DOKUMEN SUNDA LAMPAU
}

\author{
Erick Paulus' ${ }^{1)}$, Mira Suryani' ${ }^{2}$, Setiawan hadi ${ }^{3)}$, Akik Hidayat ${ }^{4)}$ \\ ${ }^{1,2,3,4)}$ Teknik Informatika, Departmen Ilmu Komputer \\ Universitas Padjadjaran \\ e-mail: erick.paulus@unpad.ac.id ${ }^{1)}$,mira.suryani@unpad.ac.id ${ }^{2}$, setiawanhadi@unpad.ac.id ${ }^{3)}$, \\ akik.hidayat@unpad.ac.id ${ }^{4)}$
}

\begin{abstract}
ABSTRAK
Beragamnya kualitas citra dokumen Sunda lampau dapat menjadi tantangan tersendiri ketika proses segmentasi baris teks dilakukan. Makalah ini memaparkan hasil investigasi dari dua metode segmentasi baris terhadap beberapa koleksi citra dokumen Sunda, yaitu metode profil proyeksi dan Seam Carving. Investigasi dilakukan secara mendalam terhadap dokumen tulisan tangan yang ditulis pada media daun lontar dan kertas. Adapun studi eksperimen perbandingan digunakan sebagai metodologi investigasi pada penelitian ini. Kedua metode tersebut diuji kemampuan kinerjanya terhadap citra berwarna dan citra biner dengan menggunakan matrik evaluasi yang disediakan pada kompetisi segmentasi tulisan tangan ICDAR 2013. Hasil eksperimen menunjukan bahwa metode profil proyeksi dapat bekerja dengan optimal pada citra biner dengan tipe tulisan yang relatif mendatar dan rata. Sedangkan metode Seam Carving mampu melakukan segmentasi baris secara non linier sehingga menghasilkan kinerja di atas $80 \%$. Dengan ditambahnya proses binerisasi pada tahapan pre-processing, maka metode Seam Carving dapat meningkat kinerjanya sampai 99\% dan jumlah baris yang tersegmentasi hampir mendekati dengan jumlah baris seharusnya.
\end{abstract}

Kata Kunci: ICDAR, profil proyeksi, Seam Carving, segmentasi baris

\begin{abstract}
The variety of image quality of old Sundanese documents can be a real challenge for the process of text line segmentation. This paper describes the results of the investigation of two text line segmentation methods against several collections of Sunda document images, ie projection profile method and Seam Carving method. The deep investigation is done on handwritten documents written on lontar and paper media. The comparative experimental study was used as an investigative methodology in this study. Both methods is tested their performance capability on colored images and binary images using the evaluation matrix provided in handwriting segmentation competition ICDAR 2013. Experimental results show that projection profile method can work optimally on binary image and the type of writing is relatively horizontal. While the Seam Carving method is able to segment the lines in a non-linear manner and produce performance above $80 \%$. With the added of binarization process in the pre-processing stage, the performance of Seam Carving method can increase up to $99 \%$ and the number of segmented lines is close to the number of groundtruth lines.
\end{abstract}

Keywords: ICDAR, line segmentation, projection profile, Seam Carving

\section{PENDAhuluan}

$\mathrm{S}$ egmentasi baris merupakan tahapan penting dan mendasar dalam proses segmentasi selanjutnya. Dengan teridentifikasinya teks baris, proses pemisahan kata, suku kata atau huruf akan lebih optimal dilakukan. Untuk kasus tulisan tangan, cara penulisan pada media tulis dapat memiliki tata letak yang beragam. Ada beberapa tulisan yang disususn secara vertikal (tulisan mandarin), horizontal (umum), dan miring. Berdasarkan data sample citra yang peneliti peroleh dari narasumber, tulisan tangan Sunda yang dibuat sekitar abad XV sampai XVII dan digores di atas daun lontar dan kertas memiliki karakteristik penulisan horizontal. Namun tidak menutup kemungkinan, terdapatnya beberapa tulisan yang tidak tersusun rapih secara horizontal. Penulisan aksara konsonan dan vokalisasi yang terkadang berhimpitan dengan baris di atas atau di bawahnya. Menurut ahli filologi, hal ini adalah wajar karena adanya siswa yang sedang belajar menulis dan menyalin dokumen penting pada jaman itu. Selain itu, kondisi fisik dokumen yang sudah mulai rapuh dan kualitas citra hasil proses akusisi data yang kurang kontras menjadi tantangan yang nyata. Oleh karena itu, peneliti perlu melakukan investigasi yang mendalam terkait metode segmentasi baris yang sudah ada saat ini sedemikian sehingga kedepannya model segmentasi yang optimal dapat dihasilkan untuk studi kasus tulisan tangan Sunda lampau.

Metode segmentasi yang umum dan menjadi dasar pada pengembangan metode segmentasi selanjutnya adalah metode profil proyeksi [1]. Beberapa penelitian menemukan bahwa cara segmentasi baris yang bersifat linier horizontal terkadang mengakibatkan kesalahan dalam proses segmentasi baris khususnya pada model tulisan 
yang miring. Untuk mengantisipasi tantangan tersebut, Saha [2] menerapkan Transformasi Hough untuk mengukur sudut kemiringan dan merotasi teks menjadi relatif horizontal [2]. Kombinasi Operasi Morfologi dan Profile Proyeksi [3] telah dilakukan terhadap dokumen tulisan tangan Kannada untuk meningkatkan kinerja dari segmentasi baris. Metode profil proyeksi dapat bekerja jika citra inputnya adalah biner (hitam atau putih). Sedangkan, proses binerisasi pada dokumen lampau khususnya tulisan tangan Sunda lampau masih menjadi tantangan yang nyata hingga saat ini[4]. Oleh karena, metode segmentasi yang bebas dari proses binersasi terus dikembangkan. Boiangiu menggunakan informasi energi sebagai algoritma segmentasi baris [5]. Penelitian yang terkait dengan pemanfaatan informasi energi terus berkembang, diantaranya adalah metode Seam Carving. Penerapan profile proyeksi pada komputasi Medial Seam dan penerapan Seam Carving pada komputasi Seperating Seam dapat menghasilkan segmentasi baris yang menjanjikan [6]. Walaupun, metode ini cukup berhasil memisahkan baris teks dan lapisan baris untuk citra keabuan dan berwarna sebagai citra input. Tim peneliti berupaya untuk melakukan investigasi mendalam terkait pengaruh tahapan binerisasi terhadap kinerja metode Seam Carving dan pengembangnya. Dengan asumsi bahwa citra yang minim derau (umumnya dilakukaan saat proses binerisasi) seharunya dapat menghasilkan segmentasi yang lebih baik.

Pada paper ini dipaparkan hasil investigasi dua metode segmentasi, yaitu metode profil proyeksi terhadap citra biner dan metode Seam Carving terhadap citra biner dan citra berwarna. Penjelasan tentang metode penelitian dan formula yang dipakai akan disajikan pada bagian II. Kemudian, kedua metode tersebut diuji dan dianalisa terhadap citra dokumen tulisan tangan Sunda yang ditulis sekitar abad XV sampai XVII. Selanjutnya, pengujian citra hasil segmentasi diukur dengan menggunakan matrik evaluasi yang dipakai untuk kompetisi segmentasi pada acara International Conference on Document Analysis and Recognition (ICDAR) 2013. Hasil eksperimen dan analisa diuraikan pada bagian III. Kesimpulan dan saran penelitian selanjutnya dipersentasikan pada bagian terakhir.

\section{METODE}

\section{A. Metode Profil Proyeksi}

Umumnya, metode profil proyeksi dimanfaatkan untuk memisahkan baris pada dokumen cetak dimana spasi antar baris terkelompokkan dengan jelas. Tetapi, ada juga hasil penelitian yang menerapkan metode profil proyeksi untuk dokumen tulisan tangan[7]. Metode profil proyeksi dapat dikelompokkan menjadi dua bagian, yaitu profil proyeksi secara vertikal atau horizontal. Profil proyeksi secara vertikal diterapkan untuk segmentasi kata atau silabi. Sedangkan profil proyeksi horizontal banyak diterapkan untuk segmentasi baris. Hal ini tentu bergantung dengan cara penulisan, contoh susunan kalimat mandarin dibuat dari atas ke bawah (secara vertikal). Namun pada umumnya, cara penyusunan kalimat dibuat secara horizontal seperti yang terdapat pada dokumen Sunda lampau.

Pada penelitian sebelumnya, Profil Proyeksi Horizontal (PPH) direpresentasikan sebagai suatu histogram dari penjumlahan piksel hitam citra biner yang diakumulasikan sepanjang baris horizontal pada suatu dokumen [8]. Secara matematika, Fungsi PPH dapat diformulasikan pada (1). Dengan ketentuan, fungsi f(x,y) adalah fungsi Piksel citra dimana $\mathrm{x}$ dan y mewakili baris dan kolom secara berurutan. Parameter $\mathrm{n}$ mewakili jumlah kolom pada suatu citra.

$P P H(x)=\sum_{1 \leq y \leq n} f(x, y)$

\section{B. Metode Seam Carving}

Ada dua tahapan proses yang dilakukan pada segmentasi baris dengan menggunakan Seam Carving, yaitu perhitungan Medial Seam dan Separating Seam.

Proses perhitugan Medial Seam, adalah sebagai berikut

1) Jika citra digital direpresentasikan secara matermatika dengan

$\mathbf{I} \in \mathbb{R}^{n \times m}$

dengan, $n$ : baris dan $m:$ kolom

2) Membentuk sub kolom dari suatu halaman menjadi $r$ kelompok, dengan lebar

$w=\lfloor m / r\rfloor$ 
3) Menerapkan deteksi tepi operasi Sobel

4) Gunakan smoothed horizontal projection profile untuk setiap potongan $\mathbf{P}_{g}^{c}$

$$
\begin{aligned}
& P_{i}^{c}=\sum_{j=k}^{k+w-1} S_{i, j}, \quad \mathbf{P}^{c}=\left\{P_{i}^{c}\right\}_{i=1}^{n}, \quad \mathbf{P}_{g}^{c}=g\left(\mathbf{P}^{c}\right) \\
& c=1, \ldots, r, \quad k \in\{1,1+w, \ldots, 1+(r-1) w\},
\end{aligned}
$$

dengan $g$ adalah tipe filter pemulusan cubic spline

5) Temukan dan sambungkan lokal maksimum terdekat dari setiap potongan

Kemudian tahap kedua, perhitungan Separating Seam adalah sebagai berikut:

1) Menghitung Fugnsi Energi dengan formula

$$
E_{i, j}=\left|\frac{I_{i, j+1}^{\sigma}-I_{i, j-1}^{\sigma}}{2}\right|+\left|\frac{I_{i+1, j}^{\sigma}-I_{i-1, j}^{\sigma}}{2}\right|
$$

paramater I $\sigma$ adalah citra asli keabuan yang dihaluskan dengan menggunakan filter Gaussian untuk simpangan baku $\sigma$

2) menghitung kumulatif nilai minimum energi $M$

$$
\begin{aligned}
& M_{y_{h}(j), 1}=E_{y_{h}(j), 1}, \\
& M_{y_{h}(j), j}=E_{y_{h}(j), j}+\min \left\{\begin{array}{l}
M_{y_{h}(j)-1, j-1} \\
M_{y_{h}(j), j-1} \\
M_{y_{h}(j)+1, j-1}
\end{array}\right.
\end{aligned}
$$

3) menghitung lintasan optimal dari energi kumulatif M. Area energi tinggi mewakili komponen teks. Sedangkan area energi rendah mewakili non-teks

\section{Proses Binerisasi}

Proses binerisasi bermanfaat untuk mereduksi derau yang terdapat pada citra input sedemikian sehingga proses segmentasi dapat dilakukan dengan lebih optimal. Nilai ambang batas pada proses binerisasi dapat ditentukan global dan atau lokal. Metode Otsu menggunakan nilai ambang batas yang diperoleh secara global [9]. Untuk dokumen Sunda kuno, hasil penelitian sebelumnya menunjukan bahwa penentuan nilai ambang batas sebaiknya didapatkan secara lokal untuk setiap sub window [4]. Salah satu metode local thresholding yang relatif baik adalah Metode Sauvola. Persamaan (7) merepresentasikan Formula Metode Sauvola. Parameter m dan s mewakili nilai mean dan standar deviasi dari warna piksel pada sub-window. Parameter k merupakan nilai konstanta dengan rentang [-1,0). Pada penelitian ini, peneliti menggunakan Nilai $\mathrm{k}=-0.2$, karena cocok untuk mendeteksi obejek hitam.

$T=m \times\left[1+k\left(1-\frac{S}{R}\right)\right]$

\section{HASIL}

Investigasi metode segmentasi baris dikelompokan menjadi tiga eksperimen, yaitu mengevaluasi kinerja metode profil proyeksi horizontal terhadap citra biner, mengevaluasi metode Seam Carving terhadap citra berwarna dan mengevaluasi pengaruh proses binerisasi terhadap metode Seam Carving dalam melakukan segmentasi baris. Adapun investigasi ini dilakukan sebagai langkah awal untuk memperbaiki kinerja metode segmentasi baris khusus analisa citra dokumen tulisan tangan. Data yang digunakan untuk melakukan investigasi adalah beberapa citra dokumen lampau dari daerah Sunda. Naskah Carita Waruga Guru(CWG) termasuk naskah termuda yang menggunakan aksara dan bahasa Sunda Kuno [10]. Naskah CWG, yang ditulis pada akhir abad ke-18, ditemukan di Kabuyutan Kawali Kabupaten Ciamis, Jawa Barat, Naskah ini ditulis menggunakan tinta hitam di atas bahan kertas Eropa dengan ukuran sekitar 20x15cm. Naskah koropak22 adalah dokumen tulisan tangan Sunda kuno yang ditulis sekitar abad XV-XVII dengan menggunakan media daun lontar dan pisau kecil. Dokumen ini ditemukan di Kabuyutan Ciburuy, Kabupaten Garut, Jawa Barat. 


\section{PEMBAHASAN}

Eksperimen pertama dilakukan untuk menguji kemapuan metode profile proyeksi horizontal terhadap citra biner. Grafik profil proyeksi diperoleh dengan menghitung jumlah pixel berwarna hitam terbanyak pada setiap baris, lihat gambar 1. Dengan menentukan batasan frekuensi warna hitam berjumlah 50 untuk dokumen CWG dan 300 untuk dokumen Koropak 22 sebagai batas ambang, maka pencarian titik minimal optimum (titik berwarna merah) dapat diperoleh dengan mudah untuk setiap lembah yang dihasilkan. Nilai ambang batas ini bergantung dari banyaknya teks pada suatu baris dan ditentukan secara manua. Nilai ambang batas ini juga dapat diperoleh dengan merujuk pada nilai median atau rata-rata dari data statistik profil proyeksi, yaitu sekitar 51 sampai 55 (lihat gambar 1.b) dan 200 sampai 302 (lihat gambar 1.d). Titik minimal optimum yang diperoleh dapat direpresentasikan sebagai lapisan baris. Untuk lembah yang menurun dan naik secara tajam sebaiknya tidak dijadikan lapisan baris, karena ada kemungkinan itu adalah derau.

Gambar 2 memberikan visualisasi hasil segmentasi lapisan baris. Namun, hasil segmentasi dari metode profil proyeksi banyak yang memotong tekstur teks. Hal ini terjadi karena metode profil proyeksi memotong citra secara horizontal. Metode ini cocok untuk tulisan tangan yang cara penulisannya relatif datar dan rata. Jika terdapat sekelompok baris teks yang ditulis miring atau vertikal, maka citra perlu dilakukan pemrosesan rotasi citra seperti Tranformasi Hough [2]. Untuk tulisan tangan pada naskah kuno, aksara Sunda umunya ditulis secara horizontal namun tidak semuanya ditulis secara datar merata. Ada beberapa silabi yang ditulis berimpitan dengan silabi pada baris diatasnya atau baris dibawahnya, seperti yang terlihat pada gambar 2. Menurut filolog, penulisan aksara yang tidak rata kemungkinan dilakukan oleh para siswa yang sedang belajar menyalin atau menulis aksara pada jaman itu. Untuk pembuatan aplikasi otomatis pengenalan tulisan tangan, tantangan seperti ini perlu diantisipasi.

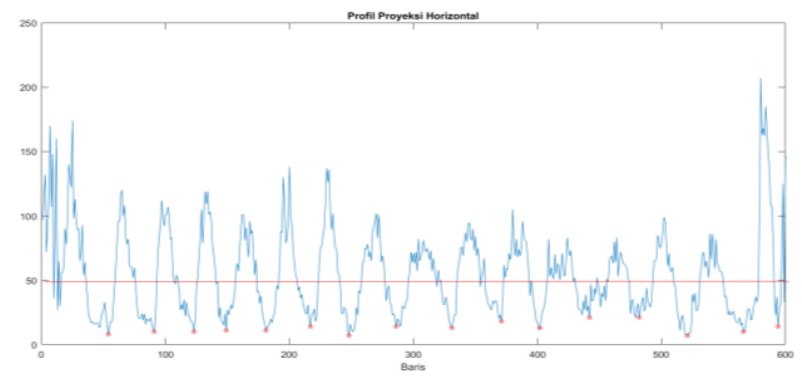

(a)

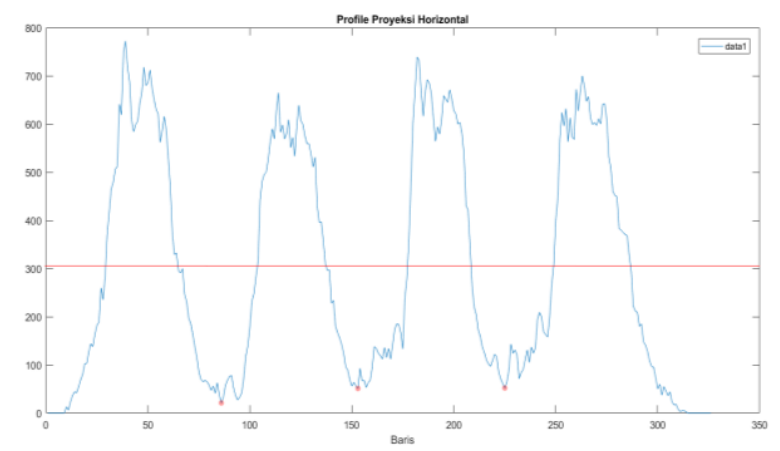

(c)

\begin{tabular}{|l|r|r|r|r||}
\hline \multicolumn{1}{|c|}{ X } & & \multicolumn{2}{c|}{ Y } \\
min & 1 & $\square$ & & \\
\hline max & 600 & $\square$ & 207 & $\square$ \\
\hline mean & 300.5 & $\square$ & 54.58 & $\square$ \\
\hline median & 300.5 & $\square$ & 51 & $\square$ \\
\hline mode & 1 & $\square$ & 23 & $\square$ \\
\hline std & 173.3 & $\square$ & 33.45 & $\square$ \\
\hline range & 599 & 200 & \\
\hline
\end{tabular}

(b)

\begin{tabular}{|l|r|r|r|r||}
\hline \multicolumn{1}{|c|}{ X } & \multicolumn{3}{c|}{ Y } \\
min & 1 & $\square$ & 0 & \\
\hline max & 326 & $\square$ & 772 & $\square$ \\
\hline mean & 163.5 & $\square$ & 300.2 & $\square$ \\
\hline median & 163.5 & $\square$ & 206.5 & $\square$ \\
\hline mode & 1 & $\square$ & 0 & $\square$ \\
\hline std & 94.25 & $\square$ & 243.5 & $\square$ \\
\hline range & 325 & & 772 & \\
\hline
\end{tabular}

(d)

Gambar. 1. Grafik profile proyeksi secara horizontal (a) CWG02 dan (c) Koropak22; Data statistik profile proyeksi (b)CWG02 dan (d) Koropak22 


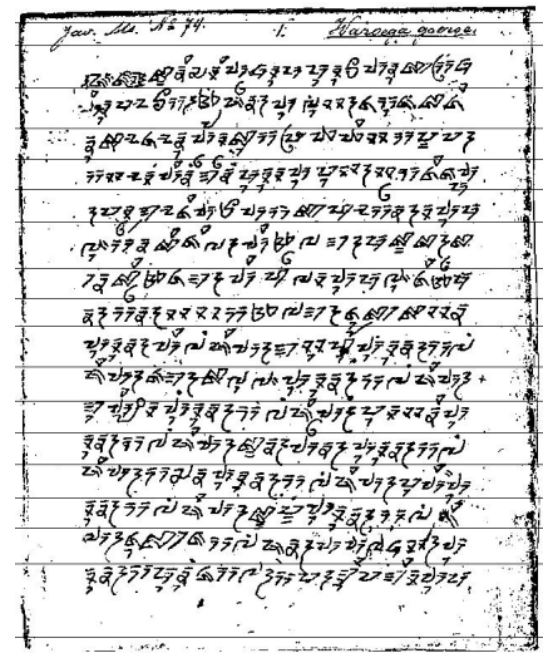

(a)

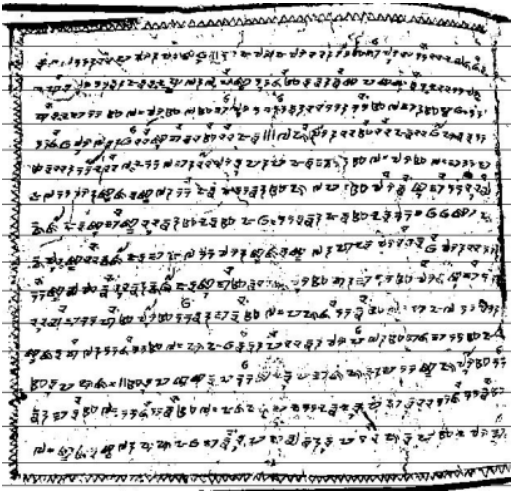

(b)

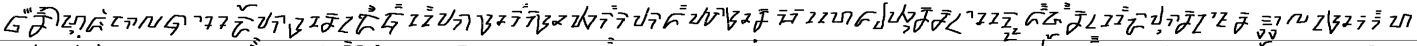

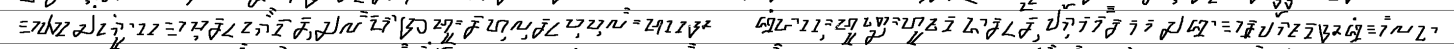

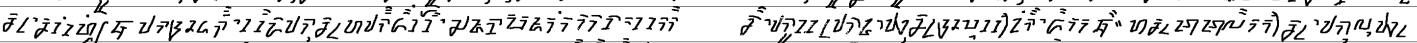

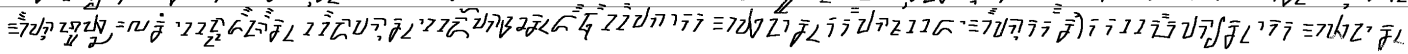

(c)

Gambar. 2. Citra hasil segmentasi lapisan baris pada citra input biner (a) CWG01, (b) CWG02 dan (c) Ciburuy22

Karena keterbatasan metode profil proyeksi, penulis mengevaluasi metode segmentasi baris lainnya yang lebih mumpuni. Eksperimen kedua dilakukan untuk menguji kemampuan metode Seam Carving dalam memisahkan lapisan antar baris yang terdapat pada naskah CWG. Untuk citra input berwarna, hasil segmentasi lapisan baris dan baris teks dengan menggunakan Metode Seam Carving dapat dikatakan cukup berhasil memisahkan teks berdasarkan baris dibanding dengan metode Projection Profile. Dengan memanfaatkan nilai energi minimum, metode Seam Carving dapat memisahkan baris teks secara non linear sehingga meminimalkan terjadi pemotongan tektur teks. Namun, gambar 3 menunjukan bahwa ada beberapa kesalahan segmentasi yang terjadi, diantaranya adalah adanya lintasan lapisan baris yang pindah jalur dan terdapat lapisan baris yang tidak terdeteksi. Perpindahan lintasan lapisan baris ini dapat terjadi ketika ada goresan yang serupa dengan warna teks hampir menutup lintasan Selain itu, pada lokasi yang berdekatan ada ruang yang menghubungkan tiga atau lebih baris teks dan yang memiliki warna hampir sama dengan area non teks sedemikian sehingga proses perhitungan energi minimum mengakibatkan pindah lintasan (lihat gambat 3c). Kesalahan kedua, yaitu tidak terdeteksinya baris teks, dapat disebabkan tidak diperolehnya titik mulai dan titik akhir lapisan yang tepat seperti yang terlihat banyak terjadi pada gambar 3a.

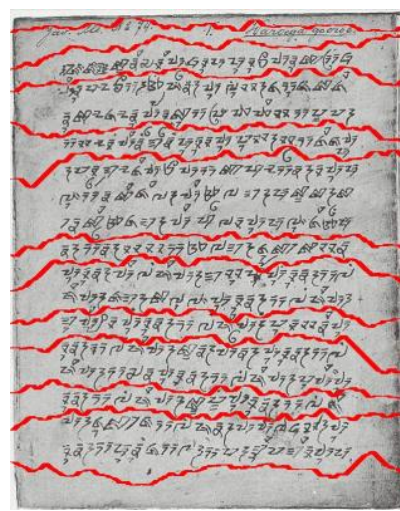

(a)

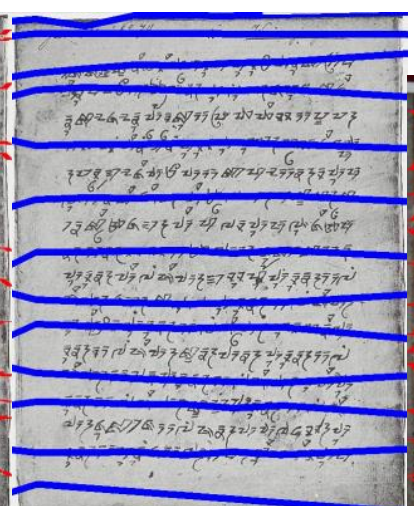

(b)

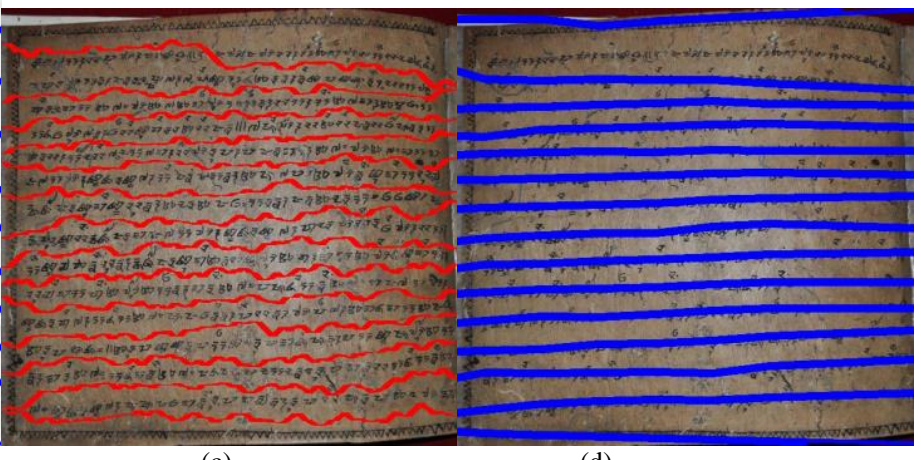

(c) (d)

Gambar. 3. Citra hasil segmentasi pada naskah Carita Waruga Guru(berurutan CWG01 dan CWG02): (a) dan (c) adalah segmentasi lapisan baris sedangkan (b) dan (d) adalah segmentasi baris teks 
Eksperimen ketiga dilakukan untuk melihat dampak proses binerisasi terhadap kinerja metode segmentasi baris. Walaupun untuk mendapatkan citra terbinerisasi tidaklah mudah diperoleh [4], peneliti melakukan pengujian dampak proses binerisasi terhadap proses segementasi. Berdasarkan penelitian sebelumnya [4], metode Sauvola menunjukan citra hasil binerisasi mendekati citra asli (ground truth). Oleh karena itu, peneliti menerapkan metode Sauvola sebagai tahapan binerisasi kemudian menerapkan metode Seam Carving untuk memisahkan lapisan baris. Adapun hasil citra tersegmentasi dapat dilihat pada gambar 4. Dari hasil percobaan, proses segmentasi baris untuk citra terbinerisasi kecil kemungkinannya terjadi kasus lapisan baris yang pindah lintasan. Gambar 4c merupakan contoh hasil segmentasi terhadap citra terbinerisasi dengan menggunakan metode Seam Carving dan metode Sauvola sedemikian sehingga jumlah baris yang dihasilkan hampir sama dengan jumlah baris seharusnya. Selanjutnya, pengujian hasil segmentasi metode Seam Carving diukur menggunakan matriks evaluasi yang dipakai oleh kompetisi segmentasi ICDAR 2013. Adapun hasil yang diperoleh untuk

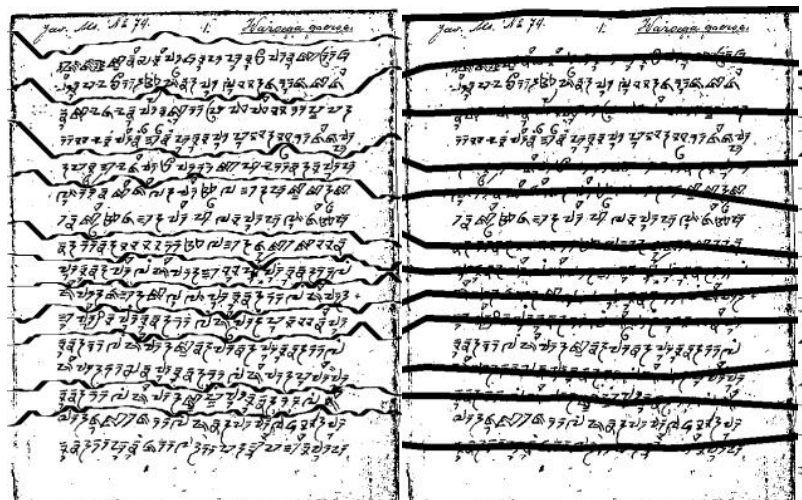

(a) (b)

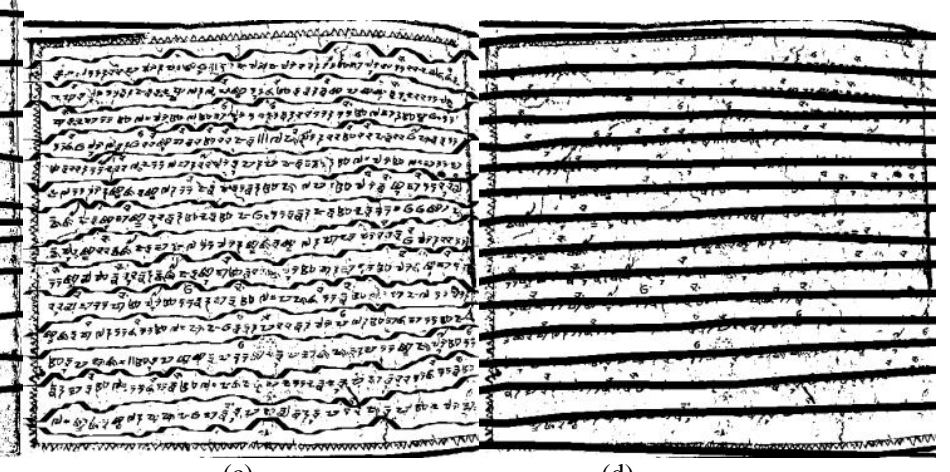

(c) (d)

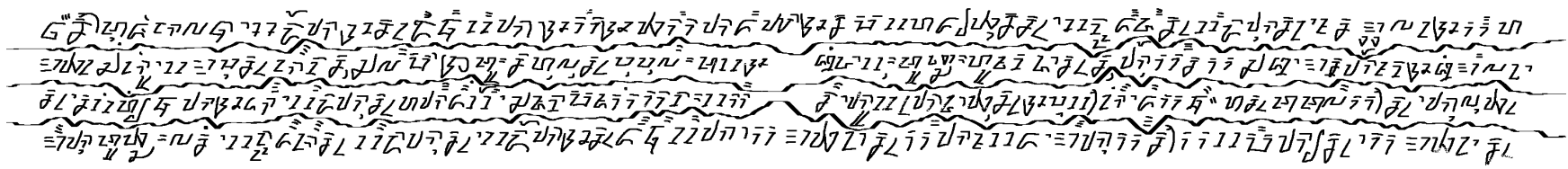

(e)

Gambar. 4. Citra hasil segmentasi yang diawali proses binerisasi menggunaka Metode Sauvola (berurutan CWG01,CWG02, Koropak22): (a), (c) dan (e) adalah segmentasi lapisan baris sedangkan (b) dan (d) adalah segmentasi baris teks

segmentasi baris dari citra berwarna dan citra terbinerisasi memiliki nilai FM secara berurutan mendekati $81 \%$ dan 99\%. Ditambah lagi, selisih jumlah baris terdekteksi dengan jumlah baris seharusnya untuk kasus citra terbinerisasi adalah 1 baris, lebih sedikit dari hasil segmentasi pada citra berwarna. Hasil ini menunjukan proses binerisasi akan memberikan pengaruh positif yang besar terhadap proses segmentasi, walaupun metode Seam Carving termasuk kategori metode yang bebas dari proses binerisasi.

Tabel 1

Matriks Evaluasi Kinerja Metode Seam Carving terhadap 12 Sample Citra Koropak 22 berdasarkan kompetisi ICDAR 2013[11]

\begin{tabular}{lcccccc}
\hline \hline & $\mathrm{N}$ & $\mathrm{M}$ & o20 & DR(\%) & RA(\%) & FM(\%) \\
\hline \hline Citra berwarna & 46 & 43 & 36 & 78,26 & 83,72 & 80,89 \\
\hline \hline Citra terbinerisasi & 46 & 47 & 46 & 100 & 97,87 & 98,92 \\
\hline \hline
\end{tabular}

\section{SIMPULAN DAN SARAN}

Investigasi terhadap kinerja metode segmentasi baris telah dilakukan dengan pengujian dilakukan terhadap beberapa sample citra dokumen Sunda lampau. Evaluasi metode profil proyeksi hanya dapat diterapkan untuk citra biner dan cocok untuk tipe tulisan tangan yang rapih tersusun secara mendatar. Sedangkan, metode Seam Carving menunjukan kinerja yang menjanjikan. Namun untuk peningkatan hasil segmentasi, metode Seam Carving perlu dikolaborasikan dengan metode binerisasi terlebih dahulu. Eksperimen menunjukan bahwa setelah dilakukan binerisasi, kinerja metode Seam Carving naik menjadi 99\%. Selain itu dari hasil investigasi, ada dua catatan penting yang masih perlu diperbaiki oleh metode Seam Carving diantaranya perpindahan jalur lapisan baris dan tergabungnya 2 atau lebih baris. Penerapan pre-processing dan post-processing dapat dijadikan pertimbangan dalam meningkatkan kinerja segmentasi baris. 


\section{UCAPAN TERIMA KASIH}

Penulis mengucapkan terima kasih atas kepada Dr. Undang Ahmad Darsa dan rekan-rekan di Sastra Sunda Unpad yang telah menjadi nara sumber dan memberikan sample citra dokumen Sunda lampau. Ucapan terima kasih juga, kami berikan kepada Univeristas Padjadjaran yang mendanai penelitian Analisa Citra Dokumen Tulisan Tangan ini melalui hibah internal dengan skema Riset Fundamental Unpad pada tahun 2017.

\section{REFERENSI}

[1] R. P. Dos Santos, G. S. Clemente, T. I. Ren, and G. D. C. Calvalcanti, "Text line segmentation based on morphology and histogram projection," Proc. Int. Conf. Doc. Anal. Recognition, ICDAR, pp. 651-655, 2009.

[2] S. Saha, S. Basu, M. Nasipuri, and D. K. Basu, “A Hough Transform based Technique for Text Segmentation,” J. Comput., vol. 2, no. 2, pp. 134$141,2010$.

[3] H. R. Mamatha and K. Srikantamurthy, "Morphological Operations and Projection Profiles based Segmentation of Handwritten Kannada Document," Int. J. Appl. Inf. Syst., vol. 4, no. 5, pp. 13-19, 2012.

[4] E. Paulus and I. N. Yulita, "Analisa dan Evaluasi Metode Binerisasi pada Tulisan Tangan Sunda kuno,” J. Tek. Inform., vol. 9, no. 1, pp. 33-37, 2017.

[5] C. A. Boiangiu, R. Ioanitescu, and M. C. Tanase, "Handwritten documents text line segmentation based on information energy," Int. J. Comput. Commun. Control, vol. 9, no. 1, pp. 8-15, 2014.

[6] N. Arvanitopoulos and S. Süsstrunk, "Seam Carving for Text Line Extraction on Color and Grayscale Historical Manuscripts," Int. Conf. Front. Handwrit. Recognit., no. Ic, pp. 726-731, 2014.

[7] L. Likforman-Sulem, A. Zahour, and B. Taconet, “Text line segmentation of historical documents: a survey," Int. J. Doc. Anal. Recognit., vol. 9, no. 2-4, pp. 123-138, 2006.

[8] E. Paulus, A. Pradana, R. Sopian, and A. Hidayat, "Analisa Ekstraksi Baris Teks pada Lontar Sunda Kuno Berbasis Profil Proyeksi,” in Seminar Nasional Matematika V UNJ, 2016, pp. 249-258.

[9] I. Pratikakis, B. Gatos, and K. Ntirogiannis, "ICDAR 2013 document image binarization contest (DIBCO 2013)," in Proceedings of the International Conference on Document Analysis and Recognition, ICDAR, 2013, pp. 1471-1476.

[10] W. Wibisana, Iskandarwassid, and T. Kartini, Lima abad sastra Sunda-Sebuah Antologi. 2000.

[11] N. Stamatopoulos, B. Gatos, G. Louloudis, U. Pal, and A. Alaei, "ICDAR 2013 Handwriting Segmentation Contest," in Proceedings of the 2013 12th International Conference on Document Analysis and Recognition, 2013, pp. 1402-1406. 